This fact sheet was created in 2000; some of the information may be out-of-date. NPIC is not planning to update this fact sheet. More pesticide fact sheets are available here. Please call NPIC with any questions you have about pesticides at 800-858-7378, Monday through Friday, 8:00 am to 12:00 pm PST.

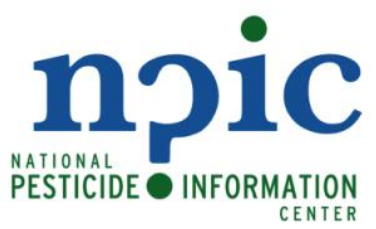

NPTN General Fact Sheets are designed to answer questions that are commonly asked by the general public about pesticides that are regulated by the U.S. Environmental Protection Agency (U.S. EPA). This document is intended to be helpful to professionals and to the general public for making decisions about pesticide use.

\title{
Methyl Bromide
}

\section{(General Fact Sheet)}

Please refer to the Technical Fact Sheet for more technical information.

The Pesticide Label: Labels provide directions for the proper use of a pesticide product. Be sure to read the entire label before using any product. A signal word, on each product label, indicates the product's potential hazard.

\section{What is methyl bromide?}

- Methyl bromide is a fumigant used against a wide variety of pests including spiders, mites, fungi, plants, insects, nematodes, and rodents (1). Introduced as a pesticide in 1932, methyl bromide was first registered in the United States in $1961(1,2)$.

- Farmers use methyl bromide primarily to treat soil to kill nematodes, fungi, and weeds $(2,3)$. Pesticide applicators also use methyl bromide to treat perishable commodities and buildings (3).

- The U.S. Environmental Protection Agency (EPA) has classified methyl bromide as a "Restricted Use Pesticide" (RUP), i.e., a pesticide that may be purchased and used only by certified applicators or persons under their direct supervision (1). This classification is due to the acute toxicity of methyl bromide. See the Pesticide Label box above.

- Methyl bromide is a colorless, non-flammable gas that has no odor except at high levels (4).

- Methyl bromide use is currently being reduced because of its ability to destroy the ozone layer (5). Beginning January 1, 2005, production and use of methyl bromide will stop in the United States, except for emergency and critical uses (5). For more information regarding the phase out of methyl bromide, visit the U.S. EPA Methyl Bromide Phase Out web site (http://www.epa.gov/docs/ozone/mbr/mbrqa.html).

- Methyl bromide is produced naturally and synthetically. The major sources in the environment are the oceans, biomass burning, and fumigation use $(7,8)$. Human contributions of methyl bromide to global sources are currently unknown $(6,7,8)$. 


\section{How does methyl bromide work?}

- Methyl bromide fills air spaces in enclosed areas and penetrates cracks, crevices, and pores in soil, commodities, and structures (9). To be an effective treatment, an appropriate concentration of methyl bromide must be contained at the application site for a given period of time (9). Pesticide applicators cover methyl bromide treatment sites with plastic tarps or tents to confine the gas $(9,10)$. Methyl bromide leaves the application site after the treatment is complete $(10,11,12,13)$.
Laboratory Testing: Before pesticides are registered by the U.S. EPA, they must undergo laboratory testing for short-term (acute) and long-term (chronic) health effects. Laboratory animals are purposely fed high enough doses to cause toxic effects. These tests help scientists judge how these chemicals might affect humans, domestic animals, and wildlife in cases of overexposure. When pesticide products are used according to the label directions, toxic effects are not likely to occur because the amount of pesticide that people and pets may be exposed to is low compared to the doses fed to laboratory animals.

- Scientists believe that methyl bromide is toxic because it damages several sites in organism's cells (7, 14). Methyl bromide binds to DNA, fats, and proteins $(7,14)$.

\section{What are some products that contain methyl bromide?}

- Brom-O-Gas ${ }^{\circledR}$

- M B C

- $\mathrm{M}-\mathrm{B}-\mathrm{R}$

- Meth-O-Gas ${ }^{\circledR}$

- Terr-O-Gas ${ }^{\circledR}$

- Other products not listed here

\section{How toxic is methyl bromide?}

\section{Animals}

- Methyl bromide is moderately toxic when fed to rats (1). See boxes on Laboratory Testing, Toxicity Category, and LD50/LC50 (Refer to Technical Fact Sheet for $\mathrm{LD}_{50}$ values).

- In short-term inhalation studies, methyl bromide is low in toxicity to mice and very low in toxicity to rats (7).

- Researchers had mice inhale methyl bromide for 13 weeks and observed lower body weights at the highest methyl bromide level (7). Mice inhaling lower methyl bromide levels did not display adverse health effects (7).

- Researchers fed dogs food containing methyl bromide for one year and did not detect any adverse health effects (15).

- Animal studies show that methyl bromide can affect the brain, kidneys, nose, heart, adrenal glands, liver, testes, and lungs $(7,16)$. Researchers have demonstrated in animal studies that a large increase in toxicity can occur with a small increase in methyl bromide exposure $(2,7)$.
LD50/LC50: A common measure of acute toxicity is the lethal dose (LD50) or lethal concentration (LC50) that causes death (resulting from a single or limited exposure) in 50 percent of the treated animals. LD50 is generally expressed as the dose in milligrams $(\mathrm{mg})$ of chemical per kilogram $(\mathrm{kg})$ of body weight. LC50 is often expressed as mg of chemical per volume (e.g., liter (L)) of medium (i.e., air or water) the organism is exposed to. Chemicals are considered highly toxic when the LD50/LC50 is small and practically non-toxic when the value is large. However, the LD50/LC50 does not reflect any effects from longterm exposure (i.e., cancer, birth defects, or reproductive toxicity) that may occur at levels below those that cause death.

\begin{tabular}{|c|c|c|c|c|}
\hline & $\begin{array}{c}\text { High } \\
\text { Toxicity } \\
\text { (Danger) }\end{array}$ & $\begin{array}{l}\text { Moderate } \\
\text { Toxicity } \\
\text { (Warning) }\end{array}$ & $\begin{array}{c}\text { Low } \\
\text { Toxicity } \\
\text { (Caution) }\end{array}$ & $\begin{array}{l}\text { Very Low } \\
\text { Toxicity } \\
\text { (Caution) }\end{array}$ \\
\hline $\begin{array}{l}\text { Oral } \\
\text { LD50 }\end{array}$ & $\begin{array}{c}\text { Less than } 50 \\
\mathrm{mg} / \mathrm{kg}\end{array}$ & $\begin{array}{c}50-500 \\
\mathrm{mg} / \mathrm{kg}\end{array}$ & $\begin{array}{c}500-5000 \\
\mathrm{mg} / \mathrm{kg}\end{array}$ & $\begin{array}{l}\text { Greater than } \\
5000 \mathrm{mg} / \mathrm{kg}\end{array}$ \\
\hline $\begin{array}{l}\text { Dermal } \\
\text { LD50 }\end{array}$ & $\begin{array}{c}\text { Less than } 200 \\
\mathrm{mg} / \mathrm{kg}\end{array}$ & $\begin{array}{c}200-2000 \\
\mathrm{mg} / \mathrm{kg}\end{array}$ & $\begin{array}{c}2000-5000 \\
\mathrm{mg} / \mathrm{kg}\end{array}$ & $\begin{array}{l}\text { Greater than } \\
5000 \mathrm{mg} / \mathrm{kg}\end{array}$ \\
\hline $\begin{array}{c}\text { Inhalation } \\
\text { LC50 }\end{array}$ & $\begin{array}{c}\text { Less than } 0.05 \\
\mathrm{mg} / \mathrm{l}\end{array}$ & $\begin{array}{c}0.05-0.5 \\
\mathrm{mg} / \mathrm{l}\end{array}$ & $0.5-2 \mathrm{mg} / \mathrm{l}$ & $\begin{array}{c}\text { Greater than } \\
2 \mathrm{mg} / \mathrm{l}\end{array}$ \\
\hline $\begin{array}{c}\text { Eye } \\
\text { Effects }\end{array}$ & Corrosive & $\begin{array}{c}\text { Irritation } \\
\text { persisting for } \\
7 \text { days } \\
\end{array}$ & $\begin{array}{c}\text { Irritation } \\
\text { reversible } \\
\text { within } 7 \text { days }\end{array}$ & $\begin{array}{c}\text { Minimal } \\
\text { effects, gone } \\
\text { within } 24 \text { hrs }\end{array}$ \\
\hline $\begin{array}{c}\text { Skin } \\
\text { Effects }\end{array}$ & Corrosive & $\begin{array}{l}\text { Severe } \\
\text { irritation at } \\
72 \text { hours }\end{array}$ & $\begin{array}{c}\text { Moderate } \\
\text { irritation at } \\
72 \text { hours }\end{array}$ & $\begin{array}{l}\text { Mild or slight } \\
\text { irritation }\end{array}$ \\
\hline
\end{tabular}




\section{Humans}

- Human experience and use history indicate that methyl bromide is highly toxic (1). Methyl bromide is corrosive to both the skin and eyes (1).

- Signs of methyl bromide poisoning may include headaches, nausea, vomiting, difficulty with vision, lack of energy, confusion, loss of coordination, slurred speech, and skin, eye, and respiratory irritation $(2,7,18,19)$. In severe poisonings, paralysis, convulsions, coma, and death may occur $(2,7,18,19)$. Signs of poisoning may be delayed only a few minutes to 48 hours following methyl bromide exposure $(2,7,19)$.

- Researchers suggest that long term exposure to low levels of methyl bromide affects the nervous system, but the evidence is not conclusive $(2,18,20,21)$.

\section{Does methyl bromide cause reproductive or birth defects?}

\section{Animals}

- Male and female rats inhaling methyl bromide did not have difficulty reproducing. Researchers observed decreased body weights for the parents and reduced growth of the offspring at the higher methyl bromide levels. At the lower methyl bromide levels, researchers did not observe adverse health effects (22).

- Pregnant rabbits inhaling methyl bromide at the highest level had a greater frequency of offspring with malformations. Researchers detected the increased frequency of malformations only when the mothers displayed adverse health effects from inhaling methyl bromide. They did not detect adverse effects at the lower methyl bromide levels $(7,22)$.

\section{Humans}

- Data are not available from accidental poisonings, work-related exposure, or other human studies regarding the reproductive and developmental toxicity of methyl bromide.

\section{Does methyl bromide cause cancer?}

\section{Animals}

- Researchers exposed rats to methyl bromide by stomach tubes and observed swelling and increased cell growth in the stomachs of rats but not cancer at the levels tested $(7,22,23)$.

- Mice inhaling methyl bromide for 2 years displayed no evidence of cancer (16).

- Researchers often test chemicals for their ability to change the genetic material of an organism as an indication of the potential to cause cancer. Evidence exists to indicate that methyl bromide can cause changes in genetic material (24).

Cancer: The U.S. EPA has strict guidelines that require testing of pesticides for their potential to cause cancer. These studies involve feeding laboratory animals large daily doses of the pesticide over most of the lifetime of the animal. Based on these tests, and any other available information, EPA gives the pesticide a rating for its potential to cause cancer in humans. For example, if a pesticide does not cause cancer in animal tests at large doses, then the EPA considers it unlikely the pesticide will cause cancer in humans. Testing for cancer is not done on human subiects.

\section{Humans}

- The U.S. EPA classifies methyl bromide as a group D carcinogen (25). This classification means that the ability of methyl bromide to cause cancer has not been determined (25). See box on Cancer.

- In a study of male chemical workers, methyl bromide exposure was suggested as a common factor in two fatal cases of testicular cancer, but researchers could not reach definite conclusions due to other factors (22). 
- A study of fumigation workers generated evidence that DNA damage may be associated with methyl bromide exposure (26).

\section{What happens to methyl bromide in the environment?}

- Methyl bromide contributes to destruction of the ozone layer $(5,6)$.

- Methyl bromide is broken down by sunlight and chemical reactions in the air (11). It is also broken down by water and microorganisms $(11,27)$.

- Ground water contamination is not likely because methyl bromide readily enters into air after use (28).

\section{How does methyl bromide affect fish and wildlife?}

- There is no data available on the direct effects of methyl bromide on birds and wild mammals (7).

- Methyl bromide is considered low in toxicity to fish. Researchers do not believe methyl bromide accumulates in fish $(7,28)$.

Date reviewed: June 2000

For more information contact: NPIC

Oregon State University, 310 Weniger Hall, Corvallis, Oregon 97331

Phone: 1-800-858-7378 Fax: 1-541-737-0761 Email: npic@ace.orst.edu

NPIC at www.npic.orst.edu EXTOXNET at http://extoxnet.orst.edu/

\section{References}

1. Pesticide Fact Sheet Number 98: Methyl Bromide. U.S. Environmental Protection Agency, Office of Pesticide Programs, U.S. Government Printing Office: Washington, DC, 1986.

2. Gehring, P. J.; Nolan, R. J.; Watanabe, P. G.; Schumann, A. M. Solvents, Fumigants and Related Compounds. In Handbook of Pesticide Toxicology; Hayes, W. J.; Laws, E. R.; Eds.; Academic: San Diego, CA, 1991; Vol. 2, pp 668671.

3. U. S. Environmental Protection Agency, Office of Prevention, Pesticides, and Toxic Substances, Office of Pesticide Programs, Washington, DC. Amended Reregistration Eligibility Decision for Methyl Bromide (soil and nonfood structural uses), EPA 738-R-09-311, May 2009.

4. A World Compendium: The Pesticide Manual, $11^{\text {th }}$ ed.; Tomlin, C. D. S., Ed.; British Crop Protection Council: Farnham, Surrey, UK, 1997; pp 824-825.

5. Protection of Stratospheric Ozone: Incorporation of Montreal Protocol Adjustment for a 1999 Interim Reduction in Class I, Group IV Controlled Substances. Fed. Regist. 1999, 64 (104), 29240-29245.

6. Butler, J. H.; Rodriguez, J. M. Methyl Bromide in the Atmosphere. In The Methyl Bromide Issue; Bell, C. H., Price, N., Chakrabarti, B., Eds.; Wiley: West Sussex, England, 1996; Vol. 1, pp 27-90.

7. World Health Organization. Methyl Bromide, Environmental Health Criteria, 166. Geneva, Switzerland, 1995.

8. McCauley, S. E.; Goldstein, A. H.; DePaolo, D. J. An isotopic approach for understanding the $\mathrm{CH}_{3} \mathrm{Br}$ budget of the atmosphere. Proc. Natl. Acad. Sci. USA 1999, 96, 10006-10009.

9. Bennett, G. W.; Owens, J. M.; Corrigan, R. M. Fumigation. In Truman's Scientific Guide to Pest Control Operations, $5^{\text {th }}$ ed.; Advanstar Communications: Cleveland, OH, 1997; pp 447-464.

10. Wang, D.; Yates, S. R.; Ernst, F. F.; Gan, J.; Gao, F.; Becker, J. O. Methyl Bromide Emission Reduction with Field Management Practices. Environ. Sci. Technol. 1997, 31, 3017-3022. 
11. ATSDR's Toxicological Profiles on CD-ROM [CD-ROM]. Agency for Toxic Substances and Disease Registry, U.S. Public Health Service. CRC: Boca Raton, FL, 1997.

12. Gan, J.; Yates, S. R.; Wang, D.; Spencer, W. F. Effect of Soil Factors on Methyl Bromide Volatilization after Soil Application. Environ. Sci. Technol. 1996, 30, 1629-1636.

13. Yang, R. S. H.; Witt, K. L.; Alden, C. J.; Cockerham L. G. Toxicology of Methyl Bromide. In Reviews of Environmental Contamination and Toxicology; Ware, G. W., Ed.: Springer-Verlag: New York, NY, 1995; Vol. 142, pp 65-85.

14. MacDonald, O. C.; Reichmuth, C. Effects on Target Organisms. In The Methyl Bromide Issue; Bell, C. H., Price, N., Chakrabarti, B., Eds.; Wiley: West Sussex, England, 1996; Vol. 1, pp 149-189.

15. Wilson, N.H.; Newton, P.E.; Rahi, M.; Bolte, H. F.; Suber, R. L. Methyl bromide: 1-Year Dietary Study in Dogs. Food Chem. Toxicol. 1998, 36, 575-584.

16. Toxicology and Carcinogenesis Studies of Methyl Bromide (CAS No. 74-83-9) in B6C3F Mice; Technical Report No. 385; U.S. Department of Health and Human Services, National Toxicology Program: Research Triangle Park, NC, 1992.

17. U. S. Environmental Protection Agency, Office of Pesticide Programs, Washington, DC. Label Review Manual. http://www.epa.gov/oppfead1/labeling/lrm/ (accessed Mar 2000).

18. Monohalomethanes: Methyl Chloride, Methyl Bromide, Methyl Iodide; Current Intelligence Bulletin No. 43: U. S. Department of Human Health \& Human Services, National Institute for Occupational Safety and Health; Atlanta, GA, 1984.

19. Wagner, S. L. The Fumigants. In Clinical Toxicology of Agricultural Chemicals. Oregon State University, Environmental Health Sciences Center: Corvallis, OR, 1981; pp 284-290.

20. Calvert, G. M.; Mueller, C. A.; Fajen, J. M.; Chrislip, D. W.; Russo, J.; Briggle, T.; Fleming, L. E.; Suruda, A. J.; Steenland, K. Health Effects Associated With Sulfuryl Fluoride and Methyl Bromide Exposure Among Structural Fumigation Workers. Am. J. Public Health. 1998, 88, 1774-1780.

21. Anger, W. K.; Moody, L.; Burg, J.; Brightwell, W. S.; Taylor, B. J.; Russo, J. M.; Dickerson, N.; Setzer, J. V.; Johnson, B. L.; Hicks, K. Neurobehavioral Evaluation of Soil and Structural Fumigators Using Methyl Bromide and Sulfuryl Fluoride. Neurotoxicol. 1986, 7, 137-156.

22. U. S. Environmental Protection Agency, Office of Research and Development, Washington, DC. Integrated Risk Information System (IRIS): Bromomethane. http://www.epa.gov/ngispgm3/iris/subst/0015.htm (accessed Mar 2000).

23. Danse, L. H. J. C.; van Velsen, F. L.; van der Heijden, C. A. Methylbromide: Carcinogenic Effects in the Rat Forestomach. Toxicol. Appl. Pharmacol. 1984, 72, 262-271.

24. Assessment of the Mutagenic Potential of Carbon Disulfide, Carbon Tetrachloride, Dichloromethane, Ethylene Dichloride, and Methyl Bromide: A Comparative Analysis in Relation to Ethylene Dibromide; Project Summary. U.S. Environmental Protection Agency, Office of Health and Environmental Assessment, U.S. Government Printing Office: Washington, DC, 1985.

25. Tracking Report. U. S. Environmental Protection Agency, Office of Pesticide Programs, U.S. Government Printing Office: Washington, DC, 1997.

26. Calvert, G. M.; Talaska, G.; Mueller, C. A.; Ammenheuser, M. M.; Au, W. W.; Fajen, J. M.; Fleming, L. E.; Briggle, T.; Ward, E. Genotoxicity in workers exposed to methyl bromide. Mutat. Res. 1998, 417, 115-128.

27. Shorter, J. H.; Kolb, C. E.; Crill, P. M.; Kerwin, R. A.; Talbot, R. W.; Hines, M. E.; Harriss, R. C. Rapid degradation of atmospheric methyl bromide in soils. Nature 1995, 377, 717-719.

28. Howard, P. H. Methyl Bromide. In Handbook of Environmental Fate and Exposure Data For Organic Chemicals; Howard, P.H., Ed.; Lewis:Chelsea, MI, 1989; Vol 1, pp 386-393.

NPIC is sponsored cooperatively by Oregon State University and the U.S. Environmental Protection Agency. Data presented through NPIC documents are based on selected authoritative and peer-reviewed literature. The information in this profile does not in any way replace or supersede the restrictions, precautions, directions or other information on the pesticide label/ing or other regulatory requirements. 